leaved trees. It seems not unlikely that it was crowded out on the higher ground, and forced to limit itself to this station which the swamps afford. In these permanent though shallow waters it clearly has an advantage over the broad-leaved forms of trees.

I am not aware that any structures resembling these knees are found among other plants. If it be the fact that they are peculiar to the Taxodium distichum, we have in this species a very remarkable case of a peculiar organ developed for a special purpose.

There is another interesting problem concerning this species. The seeds seem to germinate beneath the water. I have seen many young trees growing in what must be permanent swamp, where the soil was buried to the depth of a foot or more. I have long desired to try some experiments on this point, but have not been able to do so. I hope that some observer will undertake the inquiry.

This tree is certain to have a great economic value. Its great size, its favorable position in relation to our great water-courses, its very rapid growth and excellent timber qualities, are all calculated to commend it for use as a constructive wood. There are many million acres of land in the southern states where it could be cultivated to advantage. If kept from competition with the deciduous trees, it will do as well on any moist lowlands as in the actual swamps. Its growth is more rapid than that of any other of our timber-trees; the wood is said to be much stronger than that of any pine; it endures well in the open air without paint, as is shown by the fact that the trunks of trees killed in 1811 still stand undecayed in the swamps near the Mississippi River.

$$
\text { N. S. Shaler. }
$$

\section{RECENT BABYLONIAN RESEARCH.}

IN the Proceedings of the Society of biblical archeology for November, 1882, Mr. T. G. Pinches, the Assyrian scholar of the British museum, reports a discovery of more than ordinary interest. This is an historical notice on an inscribed cylinder, coming from the ancient city of Sippar, and belonging to Nabonidus, the last of the native Babylonian kings. The cylinder was written before Cyrus had captured Babylon, but after his conquest of the Medes. The inscription of Nabonidus, after the usual introductory formulas, relates the reconstruction of several famous temples. The first of these, the temple of the Moon-god at Haran, had been destroyed by the Medes. Being instructed by the gods Marduk and Sin to rebuild it, Nabonidus recalls for this purpose his armies from Gaza, on the borders of Egypt. $\mathrm{He}$ informs us that the temple had once before been re- stored by the Assyrian king Assurbanipal (Sardanapalus), and that he found, while engaged in the work, the inscribed cylinders of Assurbanipal and of Shalmaneser II.

The great historic event referred to in this part of the inscription is the fall of the Median empire before Cyrus the Great. When commanded to restore the temple by the god Marduk, Nabonidus replies that the Medes have destroyed it, and receives from Marduk the promise that they in their turn shall also be destroyed. Nabonidus then relates: "At the beginning of the third year, they (the gods) caused them (literally 'him,' the Median nation) to go out to war; and Cyrus, king of the land Anzan, their (lit. 'his,' i.e., the Median nation's) young servant, overthrew with his small almy the Median hosts, captured Astyages, king of the Medes, and carried him bound to his own (Cyrus's) land."

The undoubted value of this passage for the solution of the riddle left us by the conflicting testimony of the Greek writers, as to the relations of Cyrus and the Persians to Astyages and the Medes, is in part impaired by the ambiguous use of the pronouns. It is partly owing to this ambiguity that the translation. just given differs from that of Mr. Pinches, who renders: "In the third year, he [the god Marduk] caused Cyrus, king of Anzan, his young servant, to go with his little army; he overthrew the wille-spreading Sabmanda [Medes], he captured Istumegu (Astyages), king of Șabmanda, and took his treasures to his (own) land." It is difficult to say whether the words 'his servant' mean servant of Marduk, as Mr. Pinches supposes, or servant (= tributary) of the Median people; but the latter seems, for certain grammatical reasons, more probable. It is also improbable that Nabonidus, a special votary of Marduk, should speak of Cyrus, a foreigner, as a servant of the same deity, although we know that later, perhaps for state reasons, Cyrus was friendly to the worship of Marduk ( $V$. Rawl. 35). It is more probable, that, when Nabonidus mentions Cyrus as 'his small servant,' he means to say that Cyrus was a vassal prince to the Medes. The translation ' him bound' (kamûtsu, lit. 'his bondage'), instead of 'his treasures,' is well established (I. Rawl. 13, $24 \mathrm{ff}$ ), and adds not a little to the interest of the passage.

In the cuneiform annals of Cyrus, written after he had captured Babylon, we have this monarch's brief account of the war with Media (Trans. soc. bibl. arch., vii. 155 f.). After a renewed careful collation of this important passage, Mr. Pinches has published the original a second time (Proc. soc. bibl. arch., Nov., 1882). It is unfortunate that the ends of the lines are lost by mutilation of the clay tablet containing the inscription. Following is a translation of this passage: "[Astyages relied upon his troops] and marched against Cyrus, king of Anšan to [capture him?] . . . The troops of Astyages revolted against him, made him prisoner [and delivered him] to Cyrus . . . Cyrus (marched) to Ecbatana, the royal city. [He captured] the silver, gold, treasures (?), (and) possessions (?), which Ecbatana had gotten by plunder and he carried to Anšan the treasures 
and possessions which [he took?]." This version differs slightly from the one offered by Mr. Pinches, but not as to the revolt of the troops of Astyages, his delivery to Cyrus, and the capture of Ecbatana.

The accounts of Nabonidus and of Cyrus vary somewhat. The language of the former implies a battle in which Cyrus defeated the Medes and captured Astyages, but does not mention a revolt, nor the capture of Ecbatana, the Median capital. The account by Cyrus, being the state annals, is likely to be the more exact, and enters more into detail than that of Nabonidus; but the two are not at all contradictory. All that Nabonidus wished to record was the overthrow of the Median power and the capture of their king, and it was unimportant whether this took place in battle or by mutiny. It may be that. he did not know the details of the war, or it is possible that one division of the Median army gave battle, while another mutinied and delivered Astyages to Cyrus. There is an apparent difference in the two accounts as to the date of the capture of Astyages. Accorling to the Cyrus text, this event took place in the sixth year of Nabonidus, while Nabonidus says that it occurred in the 'third year.' It is, however, not clear from what point Nabonidus reckons, - perhaps from the date of his dream.

There is nothing in either of these accounts to show whether Cyrus was in any way connected by birth with Astyages. As to the relation of the countries of Media and Persia at this time, it is clear, from the language of Nabonidus, that Persia was a very small power; and if the word 'his servant' (aradsu), as applied to Cyrus, means the servant of the Medes, the conclusion would be that Cyrus was a tributaly king to the Median power. This agrees with the statement of Herodotus (i. 107), that Cambyses, the father of Cyrus, was considered by Astyages as of respectable family, but inferior to an ordinary Mede. Nicolaus of Damascus also makes Persia subject to Media (Müller, Frag. hist. Gr., iii. 399, Fr. 66).

It is certain that the mystery surrounding the relations of the Median and Persian courts and people can never be cleared up with the aids hitherto possessed. Nothing but the contemporaneous literature of these peoples themselves, and of neighboring peoples, can ever solve the problem. In another inscription Cyrus calls himself the king of Babylon, son of Cambyses king of Anšan, grandson of Cyrus king of Anšan, descendant of Ššspiš king of Anšan, royal offspring (V. Rawl. 35). This language is, however, not inconsistent with the tradition, so strongly represented by the Greeks, that the Persians were tributary to the Medes. To leave the government of subject nations in the hands of native kings was the rule in the later centuries of the Assyrian empire, and the Medes may well have practised the same policy. It was sufficient that the vassal king sent his yearly tribute, and, on proper occasion, kissed the foot of his master; but further than this was not required, and he was regarded as king in his own tribe or nation.

A word as to Anšan and Anzan. These are geo- graphical terms, - the first a city; the second apparently a land, because preceded by the sign for a country. But since this sign often represents a city also, it may well be that Ansan and Anzan are only two different ways of writing the name of the same place. This seems to be also the opinion of Professor Sayce (Trans. soc. bibl. arch., iii. 475). Probably there was both a city and a country Anšan, or Anzan. But what was Anšan? In the same inscription Cyrus calls himself king of Anšan and king of Persia (Parsu, Trans. soc. bibl. arch., vii. 155, 159). Possibly Anšan, or Anzan, was originally the name of a tribe, city, and district, to which Cyrus and his family belonged.

Another temple which Nabonidus restores is the celebrated temple of the Sun-god at Sippar. Nebuchadnezzar, he relates, had restored this edifice, and had sought for cylinders, but without success. But Nabonidus was determined to find the inscription of the founder of the temple; and his search was rewarded, for, at a depth of eighteen cubits, he came across the cylinder of Naram-Sin, son of Sargon, which no king preceding him had seen for 'three thousand two hundred years.' Accorling to the custom of the lings, he placed an inscription of his own by the sicle of that of Naram-Sin. As the date of Nabonidus was about 550 B.C., that of NaramSin would go back to 3750 B.C. But even at this time civilization must have been far advanced, for Sargon, the father of Naram-Sin (if the same as the Sargon of Agane), had in his library an astronomical work comprising seventy tablets. With this ancient date would agree the statement of Sargon II., king of Assyria 7.21-705 B.C., that three hundred and fifty princes had precederl him on the throne (Cylinder inscription, 1. 45), and the long list of Babylonian kings, numbering, before the tablet was broken, two hundred or more.

A third temple, which Nabonidus restores, is that of the goddess Anunit at Sippar. By digging he found the inscription of the last king who had re-

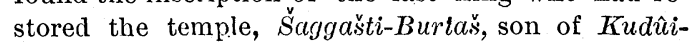
Bêl, about $10 \lesssim 0$ B.C. Anunit, goddess of this temple, seems to be the planet Venus as molning and as evening star.

These two celebrated temples at Sippar are mentioned several times in the cuneiform literature. From Berosus, also, we know that the people of Sippar were devoted to the worship of the sun, for he calls the place 'city of the sun' ('́v $\pi \dot{c} \lambda \varepsilon \iota \dot{\eta} \lambda i o v \Sigma \iota \pi \pi \hat{a}-$ poss). It was also, no doubt, as a part of this worship that the people of Sippar, whom the Assyrian king settled in the land of Samaria, burned their children in the fire (2 Kings, xvii. 31). D. G. Lyon.

\section{OCEAN WATER AND BOTTOMS.}

The ocean explored by the Norske Nordhavs expedition, 1876-7S, was a part of the North Atlantic lying to the west and north of Norway. The seawater was especially studied in order to ascertain, if possible, whether the relation subsisting between its 